\title{
Religious Education and Societal Development: The Nigerian Context
}

\author{
Azuakor, Paul Okwuchukwu',** \\ ${ }^{1}$ Department of Social Sciences, School of General Studies, Federal Polytechnic, Oko, Nigeria \\ *Correspondence: Department of Social Sciences, School of General Studies, Federal Polytechnic, Oko, Nigeria. Tel: \\ 234-803-544-0767. E-mail: frpaulokwy4@gmail.com
}

Received: July 23, 2019

Accepted: August 20, 2019 Online Published: August 25, 2019

doi:10.5430/wje.v9n4p146

URL: https://doi.org/10.5430/wje.v9n4p146

\begin{abstract}
The present writer is drawn to write on this topic based on the realization that the Nigerian society seems to be one that is bereft of the practicalisation of the ideal standards of virtues. There is apparent lack of objective measures of rightness and wrongness of actions, especially in the present dispensation, irrespective of the so much touted religiosity of Nigerians. A particular action is regarded (by implication and praxis) as right when performed by persons of a particular religion, tribe and party affiliation, but as an abomination when performed by some other persons. This beats one's imagination to the core, especially given the fact that the religio-tribal considerations appear to be the major driving force. This paper is therefore interested in the contents of the religious education of the various major religious types and how these contents that are imbibed by their adherents aid or mar the development of the Nigerian society. It was discovered, through personal observations and through the tools of analytical and deductive reasoning via library research methodology, that certain aspects of certain religious teachings have great positive impact on societal cohesion which leads to development in the Nigerian society while some others rather sow the seed of discord, injustice, hate and rancor that have led to killings, oppressions and upsurges that have characterized the Nigerian social space for decades on end and have drastically militated against social development of Nigeria. Recommendations include: religious education must consider the virtue of justice, it must adhere to the demands of rationality, it must be universalizable and not myopic, it must be dynamic, and it must be morally honest and must proceed from right conscience rather than a sick conscience.
\end{abstract}

Keywords: religious education, Christian, Islam, ATR, societal development, Nigeria

\section{Introduction}

Religion, like many concepts, has multifarious definitions. But suffice it to, in agreement with Adua (2012), take religion here as a system whereby there is recognition of the existence of a supernatural controller of the universe -God- who is the object of worship, obedience and love, that ultimately results in practical piety and morality. There are so many religions in the world with their varying religious traditions. On the other hand, for Okeke (2001), education is a society's contrivance for transmitting to its younger generation the totality of the way of life of that society. This paper construes this as the transmission of culture. But education is both process and product. The procedure of inculcating ideas, theories facts, beliefs, customs, practices etc of a given society to her younger ones is the society's process of education. The end result of the process, that is, what has been imbibed or learned by the educand is the product of education. The content could be scientific, philosophical, mathematical, religious, humanistic or otherwise. Religious education is the interest of this paper. Religious education, therefore, is the instruction on the teachings of a particular religion as contradistinguished from moral education which is wider in scope and is not confined to a particular religion and whose parameter of assessment is the consonance to rationality. So our interest here is how the teachings of the various religions impact on development of the Nigerian society. Meanwhile "societal development", which put in another way, is the "development of society" has many indicesavailability of enough food, occupation, social amenities, infrastructure, law and order in society, good government, etc. According to Agunwa (2017), "Through religion we can inculcate in individual virtual virtues like: obedience, humility, meekness, love for one's neighbor, forgiveness of injuries" (p. 202). Obedience, love for one's neighbour and forgiveness are viewed by this paper to be especially important for social integration and hence societal development. For Onah, (2017), "Man learns through his religion that certain actions are good or bad and this directs him towards living a virtuous life. This is needed for good relationship among individuals and for national development" (p. 8). And 
for Ezeanya (1988), religious education is mainly concerned with instilling the sense of the sacred in man, and reminding him that human life has a terminus a quo (point of departure) and a terminus ad quem (point of arrival). This helps for an ordered and guided outlook to life, which instigates development.

The two major religions in Nigeria are Christianity and Islam. African Traditional Religion is another force to be reckoned with as there seems to be an upsurge in adherence to this religion among many Nigerians today, especially the youth. The effective implantation and spread of the Christian faith in Nigeria took place in the $19^{\text {th }}$ century after the Portuguese Roman Catholic Missions had tried but failed in the $14^{\text {th }}$ and $15^{\text {th }}$ centuries. For Okpalike and Nwadialor (2015), during the spread of Christianity in Nigeria in the said $19^{\text {th }}$ century the resolution of the British colonial government was that the only way to redeem and regenerate the Africans was to teach them to be industrious while giving them the gospel of Christ. This has developmental import. The Islamic religion and education is said to have reached Northern Nigeria as early as the $8^{\text {th }}$ century and also to have reached Southern Nigeria, especially Yoruba land, long before the Islamic Jihad of Uthman Dan Fodio of 1804. African Traditional Religion (ATR), for its part, was the original religion of the people of Africa (and in our paper, Nigeria) before the Africans got contact with the Western world. It is still extant and had/has its developmental contributions.

\section{Christian Religious Education and the Implications for Societal Development}

Every religion aims to teach the adherents (within the confines of its intellectual, moral and practical-living repertoire) how to be good, responsible and mature human beings that are equipped with skills and competences to contribute positively to the all-round growth and development of self, one's family and society in general. Christian religion is a classical example in this matter. For Eluu (2017), "Christian religious knowledge trains the students morally and instills in them the desire to do good and be virtuous" (p. 74). The aims and objectives of Christian education in Nigeria, for Obilom (1989), are "to educate the Nigerian children both morally and intellectually, and instill in them the desire to be good citizens" (p. 15). The availability of good citizens is simply the most required factor for accelerating development in any society and Nigeria in particular, for good citizens make good educators, merchants, politicians, churchmen, scientists, etc that make for meaningful social development. For Okoye and Pongou (2014), the relative prosperity of different societies upon European contact, was seriously dependent on missionary activity; it exercised greater influence than colonial governments' and European traders' influence and it has impacted on human capital in modern Nigeria as well as having influenced cultural values and institutions. It must be noted here that missionary activity is chiefly couched on religious education, and it is clear from the above position of the cited authors that that activity led to societal development in Nigeria.

Speaking on the curriculum for Christian Religious education in Nigeria, Olugasa, Bamidele, Alonge and Onwuka (n.d.), hold: "The contents of the books are treated in a holistic manner to build spiritually, morally sound and upright citizens who would ensure the promotion of the political and socioeconomic development of Nigeria" (p. 1). As Christianity is arguably the same everywhere, it is pertinent here to look into the contents of the Christian education in Uganda and see how it compares with that of Nigeria with the hope that the adoption of the rich contents would mean developmental boon for Nigeria. In Uganda, the National Curriculum Development Centre (NCDC) made it clear that one of the national aims of education is to transmit into the students moral, ethical and spiritual integrity, human fellowship and tolerance. And for Ugandan NCDC (2009), "It is in fulfillment of this national "broad aim" that the Religious Education syllabus has been designed to assist the learner develop morally, and spiritually so as to grow into a balanced, responsible and mature person in community" (p. vi). The aims and objectives of Christian Religious Education in Uganda for NCDC include the following: (a) Development of the Christian virtues of love, joy, peace, and build a personal Christian ideal to inspire her/his development and growth to maturity; (b) To help the Christians appreciate the common elements in traditional and other religions and Christian beliefs; (c) Develop the Christian moral values of honesty, concern for others, sharing, tolerance and justice; (d) Develop personal qualities of leadership to serve others in the community. There is no society in the world, the Nigerian society inclusive, where children are taught how to love, be peaceful, accommodating, honest, altruistic, tolerant, and very importantly, just and eager to serve (Matt. 20:28) as outlined in the Ugandan model above and that society will not leap into quantum development. Corruption is rife in Nigeria today because of the lack in these outlined qualities of Christian religious education, and that same corruption is one chief bane of Nigeria's all round development, and in particular, social development.

The said Ugandan education curriculum further presents forgiveness as the solution to the problem of sin and disobedience and argues that inasmuch as people continue to fall short of what is expected of them from society and from the law of God there will be strife in society and this negates development. But imitation of God's attributes of love and forgiveness will always present a wonderful way forward in resolution of the problem of strife in 
interpersonal relationships in society, thus effecting societal development. The failed coup d'état in Nigeria of January 1966, the ensuing successful coup d'état in July of the same year, the emergent pogroms from the same year to the next, and the subsequent civil war from July 1967 to January 1970 have sown serious seeds of discord, distrust and official roguery that have all militated against development in Nigeria. Forgiveness at all fronts will go a long way to right the wrongs. Forgiveness is a cherished value of Christianity (Matt. 5: 23: "go and be reconciled with your brother first"; Lk. 23:34: "Father forgive them for they know not what they do"; Acts 7: 60: "Lord, do not hold this sin against them"). There has been deliberate policy of government in Nigeria by the post Nigeria/Biafra Civil War administrations all of which have been headed by the Nigerian victorious side as against the Bafran vanquished side, wherein the vanquished side has been copiously marginalized, but which has only but led to lopsided development and creation of suspicion, distrust, rancor and strife that have all militated against proper social integration that is an ingredient for societal development.

With reference to the Christian Religious Education and the Christian Ten Commandments, the Ugandan NCDC espouses responsible, selfless living in the society which will lead to societal cohesion and development. So for Ugandan NCDC (2009), "The learner gets guidance as to how to behave with the help of the Ten Commandments. It also teaches the learner not to mistreat and cheat the poor" (p. 5). But mistreating and cheating the poor are major causes of underdevelopment in Nigeria and the Third World in general. On this, Ezeilo (2017) states: "government's insensitivity to the yearnings and agitations of the marginalized poor communities keeps on rising, despite the resources or inputs being generated from some of these villages and communities" (pp. 35-36). Thus Christian Religious Education, if imbibed can change the situation for good.

On following Jesus the leader, the Ugandan NCDC (2009) teaches: "The learner is expected to develop understanding of the qualities Jesus had and how He served different people without discrimination. The learner further has to apply them in his/her life style" (p. 7). Discrimination along ethnic and religious lines is a major bane of development and cohesion in Nigeria. The activities of the Muslim Fulani and government's treatment of same, show dichotomy and discrimination being copiously showcased by the current Buhari administration and it becomes all the more worrisome when juxtaposed with the treatment meted out to such other groups as the Indigenous People of Biafra (IPOB). IPOB was promptly branded terrorist organization by the government and ratified by the courts of the land despite the group's avowed non-violence stance. But funny enough the Fulani herdsmen, who have ransacked villages all over the land against non-Muslims totting war weapons in a land where such an act is a criminality, killing people and raping women in the process, have never been labeled terrorist. Rather the government has the temerity, the effrontery to propose settlement of the murderous group by shamelessly proposing grazing bill and by the recently proposed but suspended Rural Grazing Area (RUGA). Government had to suspend RUGA because of serious opposition to it from the Southern and Middle-Belt zones. Thus Azuakor and Onebunne (2016) hold:

The issue of the proposed grazing bill has hurt the sensibilities of well-meaning Nigerians and has made some to see a dichotomy in the treatment of Southern Christians and the Northern Moslems. To this effect, even the killing of the IPOB and the MASSOB is seen from the ethno-religious perspective. (p. 99).

The Christian non-discrimination tenet is the remedy in this context. On selflessness and service, Jesus is presented by the Ugandan NCDC as the Christian model. Thus for NCDC (2009), "Jesus spent His life serving others in many ways. Jesus wanted to be a living example of service to others. The way Jesus served, teaches people to be servants" (p. 15). Jesus made it clear that his mission on earth was to serve and not to be served, and to give his life as a ransom for many (See Matt. 20: 28). Again, after Mary and Joseph found him in the temple where he remained without their knowledge after the annual pilgrimage, he returned with them and remained under their authority irrespective of what he was and is (See Luke 2). When Christians learn through their religious education that service is honourable, they will serve/work without seeking personal gains and thus instigate social development.

On peace, Ugandan NCDC (2009) teaches: "Peace is God given (John 14:27). It is beyond human understanding. Peace is valuable and kept by praying, observing God's commandments as well as keeping national laws" (p. 23). In Isaiah 9: 7 the coming Messiah [Jesus] is called the Prince of peace. This is in contradistinction to the murderous activities of the marauding Fulani herdsmen that Nigeria has been experiencing, and the government is taciturn about and which have retarded development of Nigeria. Thus, Nigerian Christians must continue to pray, endure and sue for peace as their religious education demands, (but not without conciliatory moves) so as to foster development in Nigeria. 


\section{Islamic Religious Education and the Consequences for Societal Development}

Ashraf, a Muslim scholar, spoke about the aims of education in general and Islamic (religious) education in particular. According to him, education should see to man's growth in all its aspects; intellectual, spiritual, physical, imaginative, scientific and linguistic, both individually and collectively, and motivate all aspects of attainment of goodness and perfection. And for Ashraf (1985), "The ultimate aim of Muslim education lies in the realization of complete submission to Allah on the level of the individual, the community and humanity at large"(p. 4). The problem will only lie in the interpretation of what this "submission to Allah" is. Again what happens to the ones who are not Moslems? Is there any freedom of choice?

With the uprising in the 1970s of greater Islamic consciousness and in the face of decline in Islamic religious education in Malaysia, the government under Tun Dr. Mahathir introduced Islamisation policy officially in 1983. This was followed by the establishment of the International Islamic University (IIUM), and the International Islamic banking system. The philosophy for establishment of the university was inspired by the recommendations of the first World Conference on Muslim Education that was held in Mecca in 1977. Thus in the spirit of Tawhid, there must be the recognition of Allah as the Absolute Creator and Master of mankind. So for Noraini and Langgulung (2008), "all disciplines of knowledge should lead towards subservience to this truth. Knowledge is a form of trust (amanah) from Allah to man, and hence man should utilize knowledge according to Allah's will" (p. 12). That means even Mathematics and Geography must be subservient to the will of Allah. The will of Allah (God) presumably must be for the good of every human being, Muslim or not. If it is, very good, otherwise, non-Muslims are in trouble. In both Malaysia and Indonesia, Muslim scholars still consider it a weakness on the part of Muslims that Islamic Religious education at all levels of education is still compartmentalized simply because the educational system itself is either totally or very largely copied from the Western model. Noraini and Langgulung (2008) actually presented Rosnani (2004) as worrying if it was not the issue of September 11, 2001 Islamic terrorist attack in the United States of America that led to Malaysian government stopping the grants usually given to schools in furtherance of Islamic education.

The Nigerian Educational Research and Development Council (NERDC) holds similar contents for the Christian and Islamic religious education syllabus. Thus for Malik, Alonge and Onwuka (n.d.), "the contents of the books are discussed in a broad way to build spiritually, morally sound and upright citizens who would ensure the development of the religious, political and socioeconomic views of Nigeria" (p. 1).

Islam also teaches tolerance, peace and kindness. For Sulaiman and Ojo (2012) "Other virtues of Islam are that Muslims were urged to imbibe the spirit of kindness and forgiveness (Q3:124)" (p. 3). Muslims are further enjoined to live in harmony and peace with other human beings, and repel evil with what is better while showing perseverance with patience (Q 3: 200).

Islamic education is usually two dimensional: intellectual knowledge (logic and reason) and spiritual knowledge (from divine revelation and spiritual experience). For Cook (2018), "Exclusive training of the intellect, for example, is inadequate in developing and refining elements of love, kindness, compassion, and selflessness, which have an altogether spiritual ambiance and can be engaged only by processes of spiritual training" (p. 4). It is evident that the honest application of all the virtues discussed above on Islamic education, for all citizens irrespective of their religious affiliations, is capable of engendering societal development.

\section{African Traditional Religion and Education for Social Development}

According to Nwosu (2004), the Igbo traditional milieu whose religion was basically African Traditional Religion (ATR), among other things, enforced rules non-coercively as in the modern state, but all the same imparted rules to achieve core civilization indices like discipline, peace and harmony. In African Traditional Religion, for Nwosu, "a fundamental impact of morality involves the domestication of humanity"(p. 1). The human being is here made to be civil rather than wild, and this is a characteristic that is necessary for development. On the contrary, a society where the human person is not domesticated but is, as in the Hobbesian state of nature, brutish and a wolf to fellow human beings, the resultant effect is sending peace, justice and development into inescapable abeyance.

The study conducted by Marashe, Ndamba and Chireshe (2009), showed that African Traditional Religion was not given due attention in primary schools in Zimbabwe. However, the Zimbabwean government and its educational ministry have seen the need to introduce it owing to the truth of the multifaceted religious nature of the country. Direct personal observations here in Nigeria also show that ATR is not given attention to in primary and secondary schools. It is only in the universities and some tertiary institutions that it is attended to in the department of religious studies. Generally, it is seen as idolatry and people, conceivably, generally do not want to return their children to idolatry by 
teaching ATR and the contents in the early formative years of the children. Even in the tertiary levels, many who study it do so chiefly for the interest of knowing the content and not necessarily with the intention of adhering to the tenets as ATR believers since the very great majority of those studying it are Christians and in many cases Christian priests and other pastors. So often, ATR is studied for comparative purposes or for purposes of proving there are principles in it that agree with the Christian ones. So the teaching of ATR in the main is done informally among the adherents.

But if no other thing, the ATR teaches justice as a way of life and in the relationship with all and sundry. This alone when imbibed is very crucial for development in Nigeria and Africa as a whole. It also teaches love and peace; both necessary virtues for social development. Citing Mara (1998), Okoro (2010) avers: "the main objective of traditional education was to inculcate a sense of social responsibility of the community to the individual members, who were becoming contributing members of the society" (p. 144). And it must be noted that the traditional education was enmeshed in traditional religion.

African morality like African traditional ethics is dependent on the African Traditional Religion. And quoting Ekeopara (2005), Ekeopara and Ogbonnaya (2014) posit, it "provides the rule for right conduct and prohibitions against wrong acts, rules, regulations, prohibitions, nso-ala, which are valid for all members of the society or community" (p. 37). Such rules include respect for life, respect for elders, respect for justice and fair play, respect for the dignity of labour, placing community interests ahead of the personal, etc. The wrong acts to be avoided include theft, adultery, lies, greed, violence, etc. The import of all this for societal development is evident.

\section{Evaluation of the Various Religious Educations with Respect to Input to Societal Development in Nigeria}

According to Ikechi-Ekpendu, Audu and Ekpendu (2016),

Religion can bring about sustainable political development through the inculcation of high sense of duty, morality, selfless service, respect for human lives, public accountability, love of one's neighbor, sense of humanity, abhorrence of violence, starting from Boko Haram crisis that has taken religio-political dimension back to the Biafra war. (p. 86).

The religious groups in Nigeria are supposed to teach these values to their members in their religious education programmes. Ideal religious education for Onovughe and Mordi (2017) "builds in men spirit of contentment and faith to a discerning encounter with the surrounding culture and seeks for its transformation. Religious education is the ground work of all subjects" (p. 14). The surrounding Nigerian culture is one of corruption, indiscipline, impunity, misguided religiosity and ethnicism. Proper religious education emanating from the rich cultures and tenets of the dominant religions has the onus of addressing the situation. So for Onovughe and Mordi, "The influence of religion and religious education on the cultural, economic, socio-political and spiritual activities in Nigerian society is both pervasive and powerful" (p. 14). It is this religious education that has built the conscience of Nigerians as to make decisions on social, economic, cultural, political and spiritual matters that relate to the life of Nigerians. For example, it is the content of religious education, in line with cherished African nay Nigerian moral norms, that has guided the Senate and the Presidency in a concerted refusal to accede to the pressure of allowing same-sex relationships in Nigeria as both Islamic, Christian and ATR doctrines see it as abominable and in no way contributive to sound Nigerian/African human relationship that can engineer social development that is in harmony with the great African values of decency and integrity.

On the other hand, for Uchem (2013), "The Nigerian society is not 'woman-friendly,' nor girl-child-friendly. On the contrary, it is 'anti-woman' and 'anti-girl-child,' like most societies across the world." (p. 542). Uchem further argues that women, in the Nigerian context, are being discriminated against in political appointments and in elections into political positions irrespective of the fact that many women are both academically and morally qualified to fill such positions, yet they are not considered because of cultural considerations. It is a male-supremacist society that hinders the attainment of the Millennium Development Goals (MDGs) through a culture that excludes women from decision-making and governance with the attendant tendency of women pulling back from leadership positions when opportunities arise. It is in this context that the contents of the Christian bible become very important in teaching Christian Religion in schools. The students must be educated according to biblical principles that in Jesus Christ there is no distinction between male and female, slaves and freeborn, Jews and Gentiles. Rather, we are all one in Christ. Thus the bible says: "There can be neither Jew nor Greek, there can be neither slave nor freeman, there can be neither male nor female - for you are all one in Christ Jesus" (Gal. 3: 28).

Christianity, Islam and ATR all teach discipline, hard-work, love, patience, peace, respect for constituted authority, respect for justice, truth, honesty, etc. All these are a sine qua non for social cohesion and harmony, which are essential 
for security and a sense of belongingness necessary for any meaningful cooperation and collaboration among citizens for meaningful all round progress and development.

On the contrary, extremism in the various religions sometimes take dangerous postures, the outcome of which has often led to disorder, killings and insecurity that have negated social development rather than cause development, irrespective of the sound contents of their religious education. Examples abound: the Islamic education which has made Muslims believe in the universal unflinching adherence to Allah, and the belief that killing of infidels by jihad ensured paradise for the Muslim have given rise to dangerous Islamic terrorist organizations in the world whose activities have led to destruction of lives and properties worth billions of dollars. This by every means has adversely affected development world over. In Nigeria, the activities of the Boko Haram have crippled social development in North East of Nigeria in particular and Nigeria in general. The nefarious activities of the Fulani herdsmen have led to huge losses in human lives- lives with mammoth potentials being thus extinguished- and this has great negative effect on social development. It has also led to mutual suspicion among various tribes in Nigeria. Persons in the Benue and Kogi are even considering severance of political affinity with the core north. This is a case of social disharmony that can never engender ideal development. Moreover a lot of economic crops have been lost to the conscienceless herdsmen who unleash their animals to farmlands and even feed cattle with people's hard-earned farm produce from the barns after sacking communities and committing homes to arson. I believe this is not what sound Islamic education teaches Muslims.

Will non-Muslims who are regarded as infidels also benefit from Islamic kindness, love and compassion as presented in the section on Islamic Education? Selflessness; is it to be for the cause that relates to non-Muslims as well? Doubtful, for it is Islamic religious teaching to subjugate the infidels. This is because in Islam, there is no dichotomy between religion, politics, commerce and social living. And because Islam is a theocracy, it is not simply a religion, but is as well a political ideology. For this, they divided the world into two: the Dar al-Islam, that is, the house of submission to the will of Allah (Muslims) and the Dar al-Harb, the house of fighting (all non Muslims that must be made to submit). For Azuakor (2016), "Fighting/struggle (jihad) to expand Islam is a religious obligation in Islam" (p. 63). It is in this light that quoting Jacques Ellul, Catholic Answers (2016) observes, "Jihad is a religious obligation. It forms part of the duties that the believer must fulfill; it is Islam's normal path to expansion" (p. 3). No wonder then Sir Ahmadu Bello, the then Sarduana of Sokoto and Premier of then Northern Region stated it clearly to Muslims in Nigeria that it was their duty to make sure that all Nigeria was made to bow to the power of Islam. This informed the registration of Nigeria into the Organisation of Islamic Conference (OIC), the introduction of the Sharia Law into Zamfara State in 2000 and the subsequent introduction of same into some other Northern states and which resistance to in Kaduna State led to huge crisis and much blood-letting; the recent registration of Nigeria into the league of Islamic nations fighting terrorism in the world. Nigeria an Islamic nation? Ridiculous!! Some statistics show that Christians are more than Muslims in Nigeria. For CIA World Factbook (2013), Nigeria has the largest Christian population as well as the largest Moslem population in Sub-Saharan Africa, and from a 2011 report, it showed that more than half the total Nigerian population (51.6\%) is Christian while Islam, ATR and other minor religions share the remaining $48.4 \%$.

But the faulty ideology of extremist Muslims that they are born to rule and subjugate others has led to the incessant murderous activities of the Fulani herdsmen who under the administration of Buhari, their kin, have committed heinous and murderous crimes in especially Christian territories across Kaduna, Taraba, Nasarawa, Benue, Kogi, Enugu, Abia, Delta, Oyo, Ogun and others. They wield weapons of war like AK 47 in a country where this is illegal and nobody is stopping them. Security operatives only become active when reprisal actions are being organized. This gives the indication that the power in the land is solidly behind the murderous Muslim Fulanis and their actions. And to make matters worse, the government is taciturn. The government has not seen any reason to label them a terrorist group when, actually, globally they are known to be the fourth most dangerous terrorist group. In Nigeria they are saints because they are furthering the will of Allah. The only interest of the government is to settle the terrorists by seeking a bill at the national assembly to create grazing colonies in every state of the federation having mapped out a staggering amount of money to be shared by all states that would comply. But this is seen by many discerning minds as no other thing than trickish Islamisation strategy. Many states are not buying into the plot in any case. In relation to the positions of the rational Muslim scholars and some passages of Quran cited in the section on Islamic religious education, it then appears that Islamic education and praxis in Nigeria need serious introspection so as to follow the more rational and humane traditions.

On the part of Christians, invasion and destruction of certain ATR shrines without the permission of the adherents in the name of purification of the land for progress have sown seeds of mistrust between them and the African Traditional religionists and thus retarding social cohesion with the attendant loss of peace, security and economic cooperation that 
lead to development. On the part of the ATR, there have been unwarranted invasion of the religious space of Christians in certain communities where Christians are forced to imbibe pagan cultural practices alien to Christianity. A point in case is the anti dust-to-dust pagan practice that forbids spouses from casting dust into the graves of their deceased partners in some parts of Anambra State, Nigeria. ATR adherents impose this on Christians in the name of culture in many communities in Awka Diocese. Resistance has led to shedding of blood in Awka and in some places together with burning of houses and opposition to royal fathers who, being Christian, dared to stand with the Christian church. There have been litigations in the courts, threats to lives, arson, and all these are anti social development. But ATR has never enjoined intolerance on the adherents. Misguided overzealousness may be to blame here.

\section{Conclusion}

Various religions teach their adherents to imbibe and live out sound moral and ethical values that go a long way to create harmony in the human society, which is necessary for societal development. Thus, for Chineke (2016), "Religion and education go hand in hand in the enlightenment and proper formation of the human mind" (p. 210). It is therefore copiously clear that religious education is vital for societal development inasmuch as the proper formation of the human mind is already a solid step in the direction of societal development. In the light of this, Ajah (2015) citing Ajidagba (1996), notes that the successive Nigerian government, have through varying educational policies demonstrated the importance of religious education for national development.

In this paper, it has been demonstrated how religious education, in our context, Christian, Islamic and ATR religious educations have laboured to implant qualities for development of society in their adherents; qualities like hard work, cooperation, forgiveness, love, truthfulness, honesty, etc. The problem however is that in certain circumstances, the living out of such values is circumscribed rather than generalized. This has created discrimination and mutual suspicion and at times violence which have, rather than cause social development, have negated it. Perseverance in right conscience, truth, honesty and the likes in religious teachings and praxis can really make the difference. If Nigerians, irrespective of their faith affiliations, follow the sound religious education of their religions and without following after selfish, extremist unofficial teachings of some extremist religionists in their midst, then the march to societal development can become a possibility and reality in Nigeria.

\section{Recommendations}

(i). Every religious teaching must be rational and for the good of human beings in general.

(ii). Conversion must be by persuasion not by violence or trick. This way it will be reasonable.

(iii). There must be adherence to the principle of "live and let live". This will ensure security of life and property.

(iv). Discrimination on grounds of religion or tribe for placement must stop; while respecting federal character, meritocracy must be the watchword.

(v). Every religion must ensure that it teaches in its religious education, respect for other religious traditions.

(vi). All the points of convergence in the three dominant religions in Nigeria like espousing the necessity of love, peace, honesty, hard work, truth, etc must be seen to be applicable, in practical terms, to all and not only to people of one's own religion.

(vii). Religious education must be conscientious and dynamic.

\section{References}

Adua, S. S. (2012). Religious studies: A tool for national development. Academic Research International, SAVAP International. Retrieved August 19, 2019 from www.journals.savap.org.pk

Agunwa, T. V. C. (2017). Religion and economic development in nation building. International Journal of Religion and Human Relations, 9(1), 198-208.

Ajah, M. (2015). Religious education and nation-building in Nigeria. Stellenbosch Theological Journal, 1(2), 263-282. http://dx.doi.org/10.17570/stj.2015,v.1n2.a12

Ashraf, S. A. (1985). New horizons in Muslim education. Cambridge: The Islamic Academy.

Azuakor, P. O. (2016). Islamic religion and global peace initiatives in the $21^{\text {st }}$ century. ANSU Journal of Arts \& Humanities, 3(3), 59-66. 
Azuakor, P. O., \& Onebunne, J. I. (2016). Fulani herdsmen rampage in Nigeria: The philosophical, ethnic and religious undertones. International Journal of Social Science and Sustainable Development, 6(1), 95-101.

Catholic Answers. (2016). Endless jihads: The truth about Islam and violence. Retrieved October 30, 2016 from http://www.catholic.com/documents/endless-jihad-the-truth-about-islam-and-violence

Chineke, P. O. (2016). The place of religion in education: A contemporary Nigerian perspective. Cultural and Religious Studies, 4(3), 204-213. https://doi.org/10.17265/2328-2177/2016.03.006

CIA World Factbook (2013). The Religions. Retrieved July 2018 from https://www.cia.gov.library/publications/the "Religions". World Factbook.

Cook, B. J. (2018). Islam-History of Islamic education, aims and objectives of Islamic education. Retrieved February 17, 2018 from http://education.stateuniversity.com/pages/2133/Islam.html

Ekeopara, C. A., \& Ogbonnaya L. U. (2014). Traditional ethics and the maintenance of social order in the Nigerian society. European Scientific Journal, 10(29), 34-46.

Eluu, P. P. (2016). The role of religion in value education in Nigeria. British Journal of Education, 4(9), $72-77$ (Special Issue).

Ezeanya, S. (1988). Christian education for our children. Onitsha: Tabansi.

Ezeilo, L. N. (2017). Who is poor and why?: Conceptual pluralism approach to poverty in Nigeria. Abuja: GiPi.

Ikechi-Ekpendu, C., Audu, S. D., \& Ekpendu, I. C. (2016). An evaluation of the role of religion in the development of Nigeria. Developing Country Studies, 6(10), 82-87.

Malik, S. H. A., Alonge, F. K., \& Onwuka, J. O. (n.d.). Islamic religious studies and national values for primary

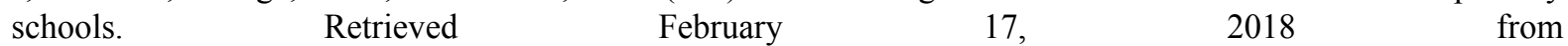
https://www.universitypressplc.com/catalogs/primary/irs-and-national-values

Marashe, J., Ndamba, G. T., \& Chireshe, E. (2009). The teaching of African Traditional Religion in primary schools in Zimbabwe: Challenges and Opportunities. Religious Education, 104(1), 38-50. https://doi.org/10.1080/00344080802615325

National Curriculum Development Centre (NCDC) (2009). Primary four Christian religious education syllabus. Kampala: NCDC.

Noraini, H., \& Langgulung, H. (2008). Islamic religious curriculum in Muslim countries: The experiences of Indonesia and Malaysia. Bulletin of Education \& Research, 30(1), 1-19.

Nwosu, O. S. (2004). Morality in African traditional society. Retrieved February 17, 2018 from https://www.google.com/search?q=ok. + Steve + Nwosu\%3A+Morality + in + African+traditional + society\&ie=utf-8 \&oe $=$ utf- 8

Obilom, J. E. C. (1989). Issues and trends on 6:3:3:4 religious education in Nigeria. Jos: Government Press.

Okeke, C. C. (2001). Introduction to social philosophy. Enugu: Academic Publishing Company.

Okoro, K. N. (2010). African traditional education: A viable alternative for peace building process in modern Africa. Journal of Alternative Perspectives in the Social Sciences, 2(1), 136-159.

Okoye, D., \& Pongou, R. (2014). Historical missionary activity, schooling, and the reversal of fortunes: Evidence from Nigeria. Retrieved august, 19, 2019 from https://www.aeaweb.org/conference/2015/retrieve.php?pdfid=874

Okpalike, C. J. B. G., \& Nwadialor, K. L. (2015). The contributions of the Christian missionaries in building the Nigerian nation, 1840-1960. Academic Journal of Interdisciplinary Studies, 4(2), 159-168.

Olugasa, O. J., Bamidele, O. H., Alonge, F. K., \& Onwuka, J. O. (n.d.). Christian religious studies and national values for primary schools. Retrieved February 17, 2018 from https://www.universitypressplc.com/catalogs/primary/christian-religious-studies-and-national-values

Onah, N. G. (2017). Religious education, peace and sustainable development in Nigeria. Afro Asian Journal of Social Sciences, 8(3), 1-13.

Onovughe, S., \& Mordi, J. F. (2017). Religious education a vital tool for sustainable development in Nigeria. International Journal of Religious and Cultural Practice, 3(1), 12-19.

Sulaiman, K. D. O., \& Ojo M. Y. (2012). The roles of religious education to peace, security and sustainable 
development in Nigeria. Journal of Humanities and Social Science, 3(6), 1-5.

The New Jerusalem Bible, Standard Edition (2002). Bandra: Saint Paul.

Uchem, R. (2013). The national Christian religious studies curriculum and the imperative for change in an era of globalization. Asian Academic Research Journal of Multidisciplinary (AARJMD), 1(6), 534-546. 